\title{
Incumbency, Redistricting, and the Decline of Competition in U.S. House Elections
}

\author{
Alan I. Abramowitz Emory University \\ Brad Alexander Emory University \\ Matthew Gunning Emory University
}

\begin{abstract}
Competition in U.S. House elections has been declining for more than 50 years and, based on both incumbent reelection rates and the percentage of close races, the 2002 and 2004 House elections were the least competitive of the postwar era. This article tests three hypotheses that attempt to explain declining competition in House elections: the redistricting hypothesis, the partisan polarization hypothesis, and the incumbency hypothesis. We find strong support for both the partisan polarization hypothesis and the incumbency hypothesis but no support for the redistricting hypothesis. Since the 1970s there has been a substantial increase in the number of House districts that are safe for one party and a substantial decrease in the number of marginal districts. However, this shift has not been caused by redistricting but by demographic change and ideological realignment within the electorate. Moreover, even in the remaining marginal districts most challengers lack the financial resources needed to wage competitive campaigns. The increasing correlation among district partisanship, incumbency, and campaign spending means that the effects of these three variables tend to reinforce each other to a greater extent than in the past. The result is a pattern of reinforcing advantages that leads to extraordinarily uncompetitive elections.
\end{abstract}

r he 2004 House elections may have been the least competitive in American history. They were certainly the least competitive of the postwar era. There was almost no change in the partisan composition of the House of Representatives. Republicans gained three seats, but this was entirely the result of a redistricting plan enacted by the Republican-controlled state legislature in Texas. Outside of Texas, Republicans lost two seats in the House. Out of 401 contests between incumbents and challengers, only five incumbents were defeated, and two of these losses were a direct result of redistricting in Texas. Astonishingly, only 22 House races in the entire country were decided by a margin of less than 10 percentage points - a record for the postwar era. At the other end of the competitive spectrum, 172 winning candidates in 2004 either had no major party opposition or coasted to victory by a margin of at least 40 percentage points.
The 2004 House elections were extraordinarily uncompetitive. However, competition in House elections has been declining for more than 50 years. One common measure of competition in elections is the reelection rate of incumbents and the reelection rate of House incumbents has increased from 87\% between 1946 and 1950 to $94 \%$ between 1952 and 1980, 97\% between 1982 and 2000, and $99 \%$ in the 2002-2004 elections. ${ }^{1}$

The reelection rate of incumbents provides only a partial perspective on competition in House elections, however. Some incumbents win easily while others barely survive and not all races involve incumbents. A broader measure of competition is the proportion of relatively close contests- those decided by less than 10 percentage points. Except for a slight increase during the 1990s, the decade during which Republicans regained control of the House for the first time in 50 years, this measure shows a steady decline in compe-

\footnotetext{
${ }^{1}$ In calculating incumbent reelection rates we exclude contests between two incumbents running in the same district due to redistricting. For additional documentation of the decline in competition in House elections, see Figures 1 and 2 included in the web appendix to this article on the Journal of Politics web site: http://www.journalofpolitics.org. Unless otherwise indicated, all percentages in this article are based on both uncontested and contested races.
}

The Journal of Politics, Vol. 68, No. 1, February 2006, pp. 75-88 
tition since the end of World War II: the proportion of House races decided by less than 10 percentage points fell from $22 \%$ between 1946 and 1950 to $21 \%$ between 1952 and 1960, 17\% between 1962 and 1970, $16 \%$ between 1972 and 1980, 12\% between 1982 and 1990, 15\% between 1992 and 2000, and 7\% in the 2002-2004 elections.

Even moderately competitive races have become increasingly rare. Between 1946 and 1960 about 40\% of House races were decided by a margin of less than 20 percentage points. In the first two elections of the twenty-first century, however, only $17 \%$ of House races were decided by a margin of less than 20 percentage points. Despite the relatively small size of the Republican majority in the House of Representatives, the close division of the electorate between Democratic and Republican identifiers, and the intense competition that has characterized the last two presidential elections, the vast majority of individual House races in 2002 and 2004 were all but decided before the fall campaigns even began.

\section{Explaining Declining Competition}

In the remainder of this article we test three hypotheses that attempt to explain declining competition in House elections: the redistricting hypothesis, the partisan polarization hypothesis, and the incumbency hypothesis. The redistricting hypothesis, which appears to enjoy the status of conventional wisdom among media commentators and editorial writers, argues that declining competition is due mainly to the effects of partisan or bipartisan gerrymandering. According to this hypothesis, state legislatures using sophisticated new computer-based technology have been skillfully drawing congressional district lines to either maximize partisan gains, creating as many districts as possible that favor the majority party by packing minority party voters into as few districts as possible, or to protect incumbents of both parties. In either case, the results of this process, according to the redistricting hypothesis, have been an increase in the number of districts that are safe for one party and a decrease in the number of marginal districts. As the New York Times editorial page recently opined, "both parties have succeeded in drawing district lines in ways that cement their current power by eliminating contested elections (New York Times 2004)." Similarly, David Broder, the dean of Washington political columnists, has argued that district lines in "most states" were drawn to protect incumbents from "the inconvenience of competition" (2004, A37).
While the refrain in popular media outlets is nearly unanimous regarding the negative consequences of redistricting, the scholarly literature is more divided. Following Mayhew's (1974) original observations on the "vanishing marginals," one political scientist found that redistricting was the cause of most of the decline in marginal districts during the 1960s (Tufte 1973). Similarly, a statistical analysis showed that incumbents benefited from reduced competition in 1992 as a result of redistricting, but that this occurred mainly in states where the redistricting was bipartisan (Lyons and Galderisi 1995). One expert on mapmaking has argued that the advent of geographic information systems (GIS) technology has made it easier than ever for politicians to draw district lines to achieve their political goals, whether those goals are to maximize majority party seats or to protect incumbents (Monmonier 2001).

On the other hand, some studies have concluded that redistricting has a neutral or positive effect on competition (Glazer, Grofman, and Robbins 1987; Gopoian and West 1984). This is not surprising because partisans drawing district lines face a fundamental tension between incumbent protection and maximizing their party's electoral potential. More often than not, the only way to shift marginal districts toward the party is to cut the safety margins of incumbents by moving reliable partisans out of their districts. For this reason, it is often the case that partisan redistricting has the effect of reducing the safety of incumbents, thereby making elections more competitive (Gelman and King 1994).

Our focus in this study is the impact of redistricting on the partisan composition of House districts, not its impact on competition in the next round of House elections. We classify a district as safe if its partisan composition strongly favors one party; we classify a district as marginal if its partisan composition is relatively evenly balanced between the two major parties.

Whether the impact of redistricting on competition is immediate or delayed may depend on factors other than the partisan composition of the new districts such as whether incumbents affected by redistricting choose to run for reelection or retire. However, changes in the partisan composition of districts should be evident immediately and have the potential to affect competition for an entire decade.

Hypothesis 1: If the redistricting hypothesis is correct, we should observe a substantial increase in the number of safe districts and a substantial decrease in 
the number of marginal districts in the elections immediately after redistricting: 1982, 1992, and 2002.

The partisan polarization hypothesis offers a somewhat different explanation of the decline in competition in House elections. According to this hypothesis, House districts have become less competitive over time, but this trend is not a result of partisan gerrymandering. Instead, Democratic districts have become more Democratic, Republican districts have become more Republican, and marginal districts have been disappearing as a result of powerful forces at work in American society, including internal migration, immigration, and ideological realignment within the electorate.

Like the redistricting theory, the partisan polarization theory has received considerable support in the popular press. In a cover story in The Atlantic, Brooks (2001) argued that profound cultural differences based on education, income, religion, and numerous other factors were leading to a growing partisan divide in the United States. Other commentators have accepted this wisdom, sometimes coloring it with references that further exaggerate the degree of division. One columnist for The Washington Post put it this way: "the red states get redder, the blue states get bluer, and the political map of the United States takes on the coloration of the Civil War" (Dionne 2003, A31).

Some in academia have repeated this characterization of a "deep cultural divide between the red states and the blue states" (Mannan 2004, 1). One widely discussed academic work goes so far as to argue that cultural divisions are so deep they have put the United States on a path toward political violence (Hunter 1995). However, other observers have argued that the idea of an increasingly polarized America is a "myth," and that Americans are remarkably moderate and increasingly tolerant in their political views (Fiorina, Abrans, and Pope 2004). Staking out something of a middle ground in a detailed study of voting trends in twelve states, Gimpel and Shuknecht (2003) make a strong case that a range of complex geographicallylinked factors such as immigration, migration, education, income, and religion are contributing to growing geographic divergence in party loyalties. Stonecash, Brewer, and Mariani (2003) and Oppenheimer (2005) have proposed similar explanations for growing partisan divergence among congressional districts. Evidence of this trend can also be seen at the county level where the number of counties dominated by one party and the proportion of voters living in such counties have increased dramatically over the past several decades (Bishop 2004).
There is also evidence that growing ideological polarization at the elite level has made it easier for voters to choose a party identification on the basis of their ideological preferences (Abramowitz and Saunders 1998; Jacobson 2000). Therefore what many observers describe as "polarization" might more accurately be described as "sorting" as voters bring their policy and partisan preferences into alignment (Levendusky 2004). As a result of this sorting, southern and border states that once regularly elected conservative Democrats have been trending Republican (Black and Black 2004) while urban and suburban areas in the North that once regularly elected moderate and liberal Republicans have been trending Democratic (Paulson 2004).

Hypothesis 2: If the partisan polarization hypothesis is correct, we should find that the number of safe districts has been steadily increasing and the number of marginal districts has been steadily decreasing, with most of this change occurring between redistricting cycles.

In contrast to both the redistricting hypothesis and the partisan polarization hypothesis, the incumbency hypothesis argues that declining competition in House elections is due less to change in the partisan composition of House districts than to the growing advantages of incumbency. There are two types of advantages to which incumbent politicians might owe their extraordinarily high reelection rates: advantages that derive from holding office, and campaign-related advantages. Although the debate is ongoing, recent research points strongly toward the second set of advantages, especially those involving challenger resources, as the cause of the recent spike in incumbent electoral performance (Abramowitz 1991; Campbell 2002, 2003; Cox and Katz 1996; Kazee 1983; Levitt and Wolfram 1997).

Hypothesis 3: If the incumbency hypothesis is correct, we should find that even in marginal districts, competition is now relatively rare because of the inability of challengers to compete financially. We should also find that the decline in competition in House elections has been most evident in races involving incumbents, with competition declining less drastically in open seat races.

\section{Data and Measures}

We have collected data on competition in U.S. House elections since the end of World War II. These data include the percentage of the major party vote won by the Democratic and Republican candidates in every 
House election between 1946 and 2004, the party affiliation of the incumbent Representative in each district, whether the incumbent was running for reelection, the previous political experience of the challenger, the percentage of the major party vote won by the Democratic and Republican presidential candidates in every House district in the current or most recent presidential election in every election between 1956 and 2004 except for the 1962 midterm election, and total campaign spending by the Democratic and Republican candidates in every House contest between 1972 and 2002. ${ }^{2}$

We use the normalized presidential vote in each House district in the current or most recent presidential election as a measure of the partisan composition of the district. The normalized presidential vote is computed by subtracting the Democratic presidential candidate's percentage of the major party vote in the entire nation from his percentage of the vote in the district. For the 2004 election, we used the results of the 2000 presidential election to construct this measure because 2004 presidential election results were not yet available for individual House districts.

The normalized presidential vote provides us with a measure of district partisanship that is comparable across districts and elections and independent of the results of congressional elections themselves. An examination of the relationship between the normalized presidential vote and the results of House elections during the 1980s, 1990s, and the first two elections of the twenty-first century strongly supports the validity of the normalized presidential vote as a measure of district partisanship. ${ }^{3}$ The Democratic share of the normalized presidential vote was strongly related to the Democratic share of the vote in contested House races during each decade and this relationship became stronger over time. The correlation (Pearson's $r$ ) between the normalized Democratic

\footnotetext{
${ }^{2}$ We would like to thank Gary Jacobson for providing us with the data for the 1946 through 2000 House elections. Data on the 2002 and 2004 House elections were collected by the authors from various sources including the 2004 edition of The Almanac of American Politics, and the c-span.org web site. Between 1946 and 1968 a number of states with more than one House district made use of at-large House districts. For an explanation of the treatment of at-large House elections between 1946 and 1968, see the web appendix to this article which is available on the Journal of Politics web site: http://www.journalofpolitics.org.

${ }^{3}$ The validity of the normalized presidential vote as a measure of district partisanship does not appear to be affected by the presence of a strong third party or independent presidential candidate on the ballot. For a discussion of this issue, see the web appendix to this article on the Journal of Politics web site: http://www. journalofpolitics.org.
}

presidential vote and the Democratic share of the House vote increased from .65 during the 1980s to .78 during the 1990s and .82 in the 2002-2004 elections. As a result, the percentage of safe districts won by the candidate of the majority party increased from $89 \%$ during the 1980 s to $94 \%$ during the 1990 s and $97 \%$ in 2002-2004, the percentage of leaning districts won by the candidate of the majority party increased from $72 \%$ during the 1980 s to $80 \%$ during the 1990 s and $85 \%$ in $2002-2004$, and the percentage of marginal districts won by the candidate of the majority party increased from 59\% during the 1980s to $61 \%$ during the 1990 s and $69 \%$ in $2002-2004$.

\section{Findings}

Since the 1994 election, Republicans have maintained a narrow majority in the House of Representatives. The number of Republican seats has ranged between 223 and 232 while the number of Democratic seats has ranged between 203 and 212. ${ }^{4}$ Because of the small size of the Republican majority, control of the House appears to be at stake in every election. Despite the appearance of national competitiveness, however, the number of competitive House contests has fallen since 1994, reaching record low levels in 2002 and 2004. One possible explanation for this decline in competition in individual House races is that there are fewer marginal House districts than in the past.

Figure 1 displays the numbers of marginal and safe House districts before and after each recent redistricting cycle. Marginal districts are those in which the two-party division of the presidential vote was within plus or minus 5 percentage points of the two-party division of the national presidential vote; safe districts are those in which the presidential vote was at least 10 percentage points more Democratic or Republican than the national presidential vote. By using the normalized presidential vote to measure the partisan composition of House districts before and after redistricting, we can evaluate the impact of redistricting on the numbers of marginal and safe districts. If redistricting were responsible for the decline in the competitiveness of House districts, we would expect to see a substantial decrease in the number of marginal districts and a substantial increase in the number of safe districts immediately after redistricting.

\footnotetext{
${ }^{4}$ We count Rep. Bernie Sanders of Vermont, who is technically an independent but caucuses with the Democrats, as a Democrat. Sanders has had either no Democratic opposition or nominal Democratic opposition in recent elections. Excluding his seat from the analysis would have no effect on our results.
} 


\section{Figure 1 Numbers of Safe and Competitive Districts Before and After Redistricting, 1980-2002}

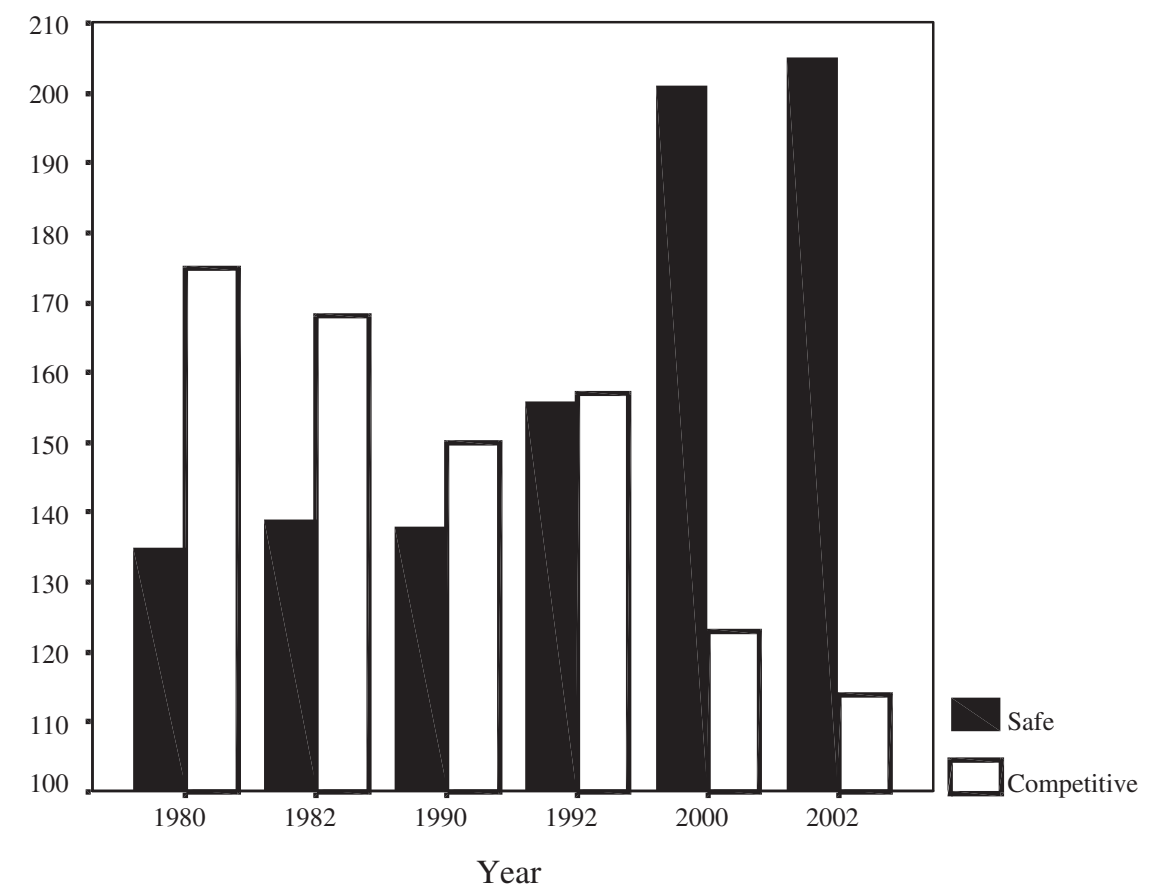

Source: Data compiled by authors.

The evidence displayed in Figure 1 shows that at the national level redistricting had a negligible impact on the competitiveness of House districts in each of the last three redistricting cycles. This does not mean that redistricting was never used to reduce the competitiveness of House districts in a state. In California, for example, the number of marginal districts went from 14 in 2000 to only four in 2002. But this was not part of a national trend. Outside of California, the number of marginal districts increased slightly between 2000 and 2002, going from 109 to 112 .

Our evidence shows that control of redistricting had no effect on change in the proportions of safe and marginal districts between 2000 and 2002. Regardless of whether there was one-party control of redistricting, divided-party control, or nonpartisan/judicial control, there was very little change in the proportions of safe and marginal districts. In states in which redistricting was done by nonpartisan commissions or courts, the proportion of marginal districts decreased from $25 \%$ in 2000 to $24 \%$ in 2002 while the proportion of safe districts increased from $44 \%$ in 2000 to $51 \%$ in 2002; in states in which redistricting was done by partisan state legislatures, the proportion of marginal districts decreased from $29 \%$ in 2000 to $28 \%$ in 2002 while the proportion of safe districts decreased from $46 \%$ in 2000 to $45 \%$ in 2002 . There is no evidence that redistricting by nonpartisan redistricting commissions or courts resulted in more competitive districts than redistricting by partisan state legislatures. ${ }^{5}$

The most significant changes in the competitiveness of House districts occurred between redistricting cycles. This pattern is consistent with the partisan polarization hypothesis. As a result of population movement, immigration, and ideological realignment within the electorate, Republicans are increasingly surrounded by other Republicans and Democrats by other Democrats (Oppenheimer 2005). This trend has been evident since the 1970s, but it appears to have accelerated in recent years. Between 1992 and 2004, the number of marginal districts fell from 157 to 112 while the number of safe districts rose from 156 to 208.

The effect of this increase in partisan polarization has been magnified by the growing consistency of voting behavior between presidential and House elections. The correlation between the Democratic percentage of the House vote and the Democratic percentage of the presidential vote in House districts increased from .58 during the 1970 s to .82 in 2002-2004. This was not simply a result of partisan

${ }^{5}$ For additional evidence of the failure of nonpartisan redistricting commissions to increase competition in congressional and state legislative elections, see Hill (2005). 
TABLE 1 Percentages of Democratic and Republican Incumbents in Low-Risk and High-Risk Districts by Decade

\begin{tabular}{ccccc}
\hline & $\mathbf{1 9 7 2 - 1 9 8 0}$ & $\mathbf{1 9 8 2 - 1 9 9 0}$ & $\mathbf{1 9 9 2 - 2 0 0 0}$ & $\mathbf{2 0 0 2 - 2 0 0 4}$ \\
\hline Republicans & & & & \\
Low-Risk & 23.2 & 31.5 & 35.0 & 40.8 \\
High-Risk & 21.5 & 16.1 & 16.4 & 11.3 \\
Democrats & & & 39.5 & 51.1 \\
Low-Risk & 24.5 & 24.5 & 25.5 & 16.4 \\
High-Risk & 41.4 & 35.4 & \\
\hline
\end{tabular}

Note: Low-risk districts are those in which share of major party vote for presidential candidate of incumbent's party was at least 10 percentage points greater than national vote share. High-risk districts are those in which share of major party vote for presidential candidate of incumbent's party was less than national vote share.

Source: Data compiled by authors.

realignment in the South: the trend was evident in congressional districts outside of the South as well as those in the South. This growing consistency appears to reflect an increase in partisan voting in both presidential and congressional elections since the 1980s (Bartels 2000).

As a result of both increased partisan polarization and increased partisan consistency in voting behavior, far fewer Representatives now occupy high-risk districts, districts that are less supportive of their party than the national average, and far more Representatives now occupy low-risk districts, districts that that are at least 10 percentage points more supportive of their party than the national average. Table 1 displays the average percentage of Democratic and Republican members occupying high-risk and low-risk districts in each decade since the 1970s. During this time period, the percentage of Republicans in high-risk districts has fallen from $22 \%$ to $11 \%$ and the percentage of Democrats in high-risk districts has fallen from $41 \%$ to $16 \%$. At the same time, the percentage of Republicans in low-risk districts has risen from $23 \%$ to $41 \%$ and the percentage of Democrats in low-risk districts has risen from 24\% to 51\%. Between 1972 and 2004, the total number of members representing high-risk districts fell from 157 to 97 while the total number of members representing low risk districts rose from 50 to 203.

The changing partisan composition of House districts has important implications for competition in House elections. Compared with 30 years ago, a much smaller proportion of members now represent districts which, based on presidential voting patterns, favor the opposing party: fewer Republicans represent Democratic-leaning districts and far fewer Democrats represent Republican-leaning districts. These highrisk districts account for a disproportionate share of incumbent defeats and party turnover in House elec- tions. For example, in the 1994 midterm election in which Republicans regained control of the House of Representatives, 32\% of Democratic incumbents in high-risk districts were defeated compared with only $7 \%$ of Democratic incumbents in all other districts. Only 34\% of Democratic seats in 1994 were in highrisk districts, but $70 \%$ of Democratic seat losses occurred in these high-risk districts.

Compared with the 1970s and 1980s, a much larger proportion of members now represent districts which, based on presidential voting patterns, strongly favor their own party: more Republicans represent solidly Republican districts and more Democrats represent solidly Democratic districts. These low-risk districts account for a disproportionate share of uncontested and one-sided races. Even under the most unfavorable circumstances, incumbents in such districts are rarely defeated. For example, in the 1994 election not one of the 69 Democratic incumbents representing a low-risk district was defeated.

Growing partisan polarization means that both parties have far fewer seats at risk in House elections than they did 30 years ago or even 10 years ago. However, the increased number of safe districts does not completely explain the lack of competition in recent House elections. The partisan composition of a House district is not the only factor determining whether that district is going to have a competitive race. Even in marginal districts, those with the most even balance of party support, only a small minority of House contests in 2002 and 2004 were actually competitive. Only $11 \%$ of contests in these marginal districts were decided by less than 10 percentage points and only $20 \%$ were decided by between 10 and 20 percentage points. More than two-thirds of House races in marginal districts were blowouts in which the winning candidate was unopposed or received at least $60 \%$ of the major party vote. 
Competition in marginal districts has been declining for decades. Figure 2 displays the trend since the 1950s in the percentage of highly competitive races, those decided by less than 10 percentage points, in marginal and safe House districts. Throughout this time period the percentage of highly competitive races was substantially greater in marginal districts than in safe districts. However, notwithstanding a brief surge in competition during the 1990s, the percentage of highly competitive races in marginal districts fell dramatically between the 1950s and the first decade of the twenty-first century. By 2002-2004, the percentage of highly competitive races in marginal districts was only slightly greater than the percentage of highly competitive races in safe districts during the 1950s.

One possible explanation for the lack of competition in many marginal districts is the advantage of incumbency. Because of their ex-officio advantages (Mayhew 1974), their ability to raise huge campaign war-chests, and the inability of most of their challengers to raise the funds required to mount serious campaigns, the large majority of House incumbents, even in marginal districts, win reelection by wide margins. When the advantage of incumbency is removed, however, there is a much greater chance of a competitive contest. The data displayed in Table 2 show that in these marginal districts there was a huge difference in competitiveness between contests with running incumbents and contests for open seats. In districts with running incumbents, only $5 \%$ of the races were highly competitive and only $19 \%$ were moderately competitive. In contrast, in districts without incumbents, $45 \%$ of the races were highly competitive and another $23 \%$ were moderately competitive.

Figure 3 displays the trend in the percentage of competitive open seat and incumbent races since the end of World War II. In the first three elections of the postwar era there was very little difference in the competitiveness of open seat and incumbent races. Since the 1950s, however, open-seat House races have generally been much more competitive than those with incumbents. Moreover, while the extent of competition for open seats has changed very little, there has been a fairly steady decline in competition for seats in which incumbents were running. During the 1950s, about $40 \%$ of races with incumbents were at least moderately competitive. In the first two elections of

Figure 2 Competition in Marginal and Safe Districts, 1952-2004

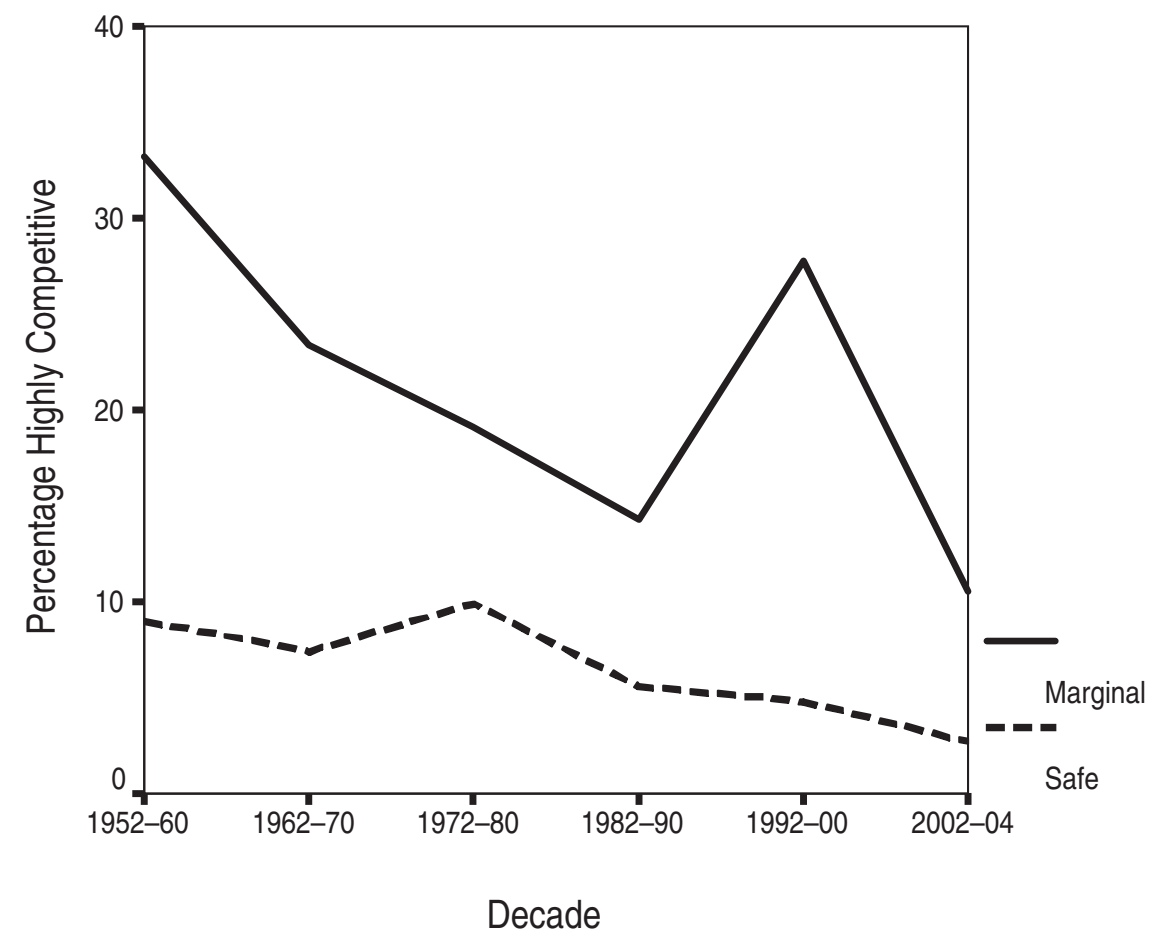

Note: Marginal districts are those in which Democratic presidential candidate's percentage of major party vote is within 5 points of national percentage; safe districts are those in which Democratic presidential candidate's percentage of major party vote is more than 10 points above or below national percentage.

Source: Data compiled by authors. 
Figure 3 Competition in Incumbent and Open Seat House Races by Decade

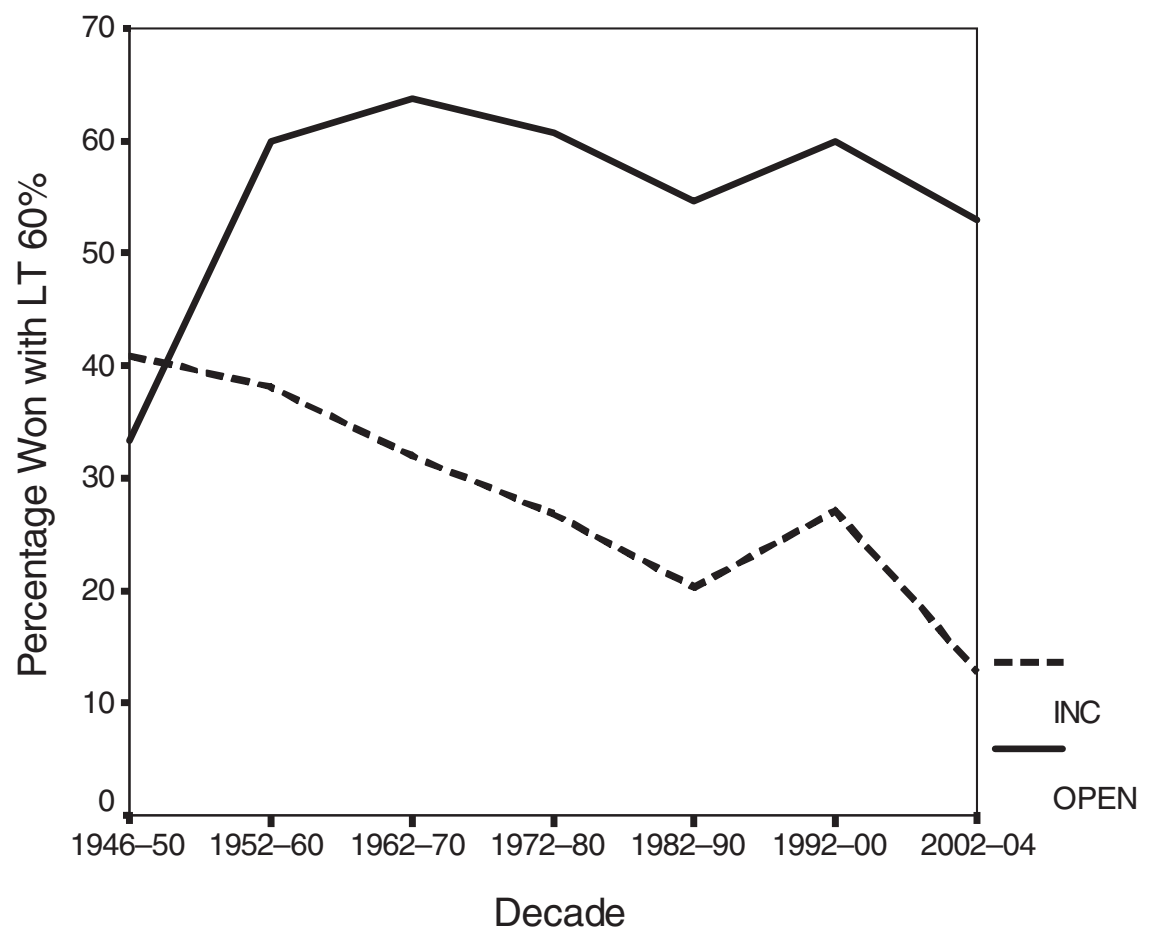

Source: Data compiled by authors.

TABle 2 Competition in Marginal House Districts by Type of Contest, 2002-2004

Type of Contest

\begin{tabular}{lcc}
\cline { 2 - 3 } $\begin{array}{l}\text { Winner's \% of } \\
\text { House Vote }\end{array}$ & Open Seat & $\begin{array}{c}\text { Running } \\
\text { Incumbent }\end{array}$ \\
\hline $\begin{array}{l}\text { Uncontested } \\
\text { or 70+ }\end{array}$ & $3 \%$ & $20 \%$ \\
$60-70$ & 29 & 55 \\
$55-60$ & 23 & 19 \\
$50-55$ & 45 & 5 \\
& & \\
Total & $100 \%$ & $100 \%$ \\
(n) & $(31)$ & $(197)$ \\
\hline
\end{tabular}

Note: Marginal districts are those in which Democratic presidential candidate's percentage of major party vote is within 5 points of national percentage.

Source: Data compiled by authors.

the twenty-first century, however, only about $15 \%$ of races with incumbents were at least moderately competitive.

Why do so few incumbents face stiff competition even in districts whose partisan composition could make them vulnerable? Part of the answer appears to be that the large majority of challengers in these races lack the financial resources to wage competitive
TABLE 3 Competition in High-Risk Incumbent Districts by Challenger Spending, 1998-2002

\begin{tabular}{lccc}
\hline & \multicolumn{3}{c}{ Challenger Spending } \\
\cline { 2 - 4 } Challenger's & \multicolumn{3}{c}{$\mathbf{\$ 5 0 0 , 0 0 0 -}$} \\
\% of Vote & $\mathbf{\$ 0 - 4 9 9 , 9 9 9}$ & $\mathbf{9 9 9 , 9 9 9}$ & $\mathbf{\$ 1 , 0 0 0 , 0 0 0 +}$ \\
\hline LT 30 & $16 \%$ & $0 \%$ & $0 \%$ \\
$30-40$ & 48 & 25 & 3 \\
$40-45$ & 29 & 29 & 21 \\
$45+$ & 7 & 46 & 76 \\
Winners & $0 \%$ & $14 \%$ & $27 \%$ \\
(n) & $(132)$ & $(28)$ & $(33)$ \\
\hline
\end{tabular}

Note: Risky districts are those in which percentage of major party vote for presidential candidate of incumbent's party is less than national percentage.

Source: Data compiled by authors.

campaigns. The data displayed in Table 3 shows that in elections between 1998 and 2002 in high-risk districts - those with the most unfavorable partisan composition for incumbents-there was a very strong relationship between the challenger's campaign spending and the competitiveness of the race. Seventy-six percent of contests in which the challenger spent at least a million dollars were highly competitive and $27 \%$ 


\section{Figure 4 Financial Competitiveness of House Challengers by Type of District, 1972-2002}

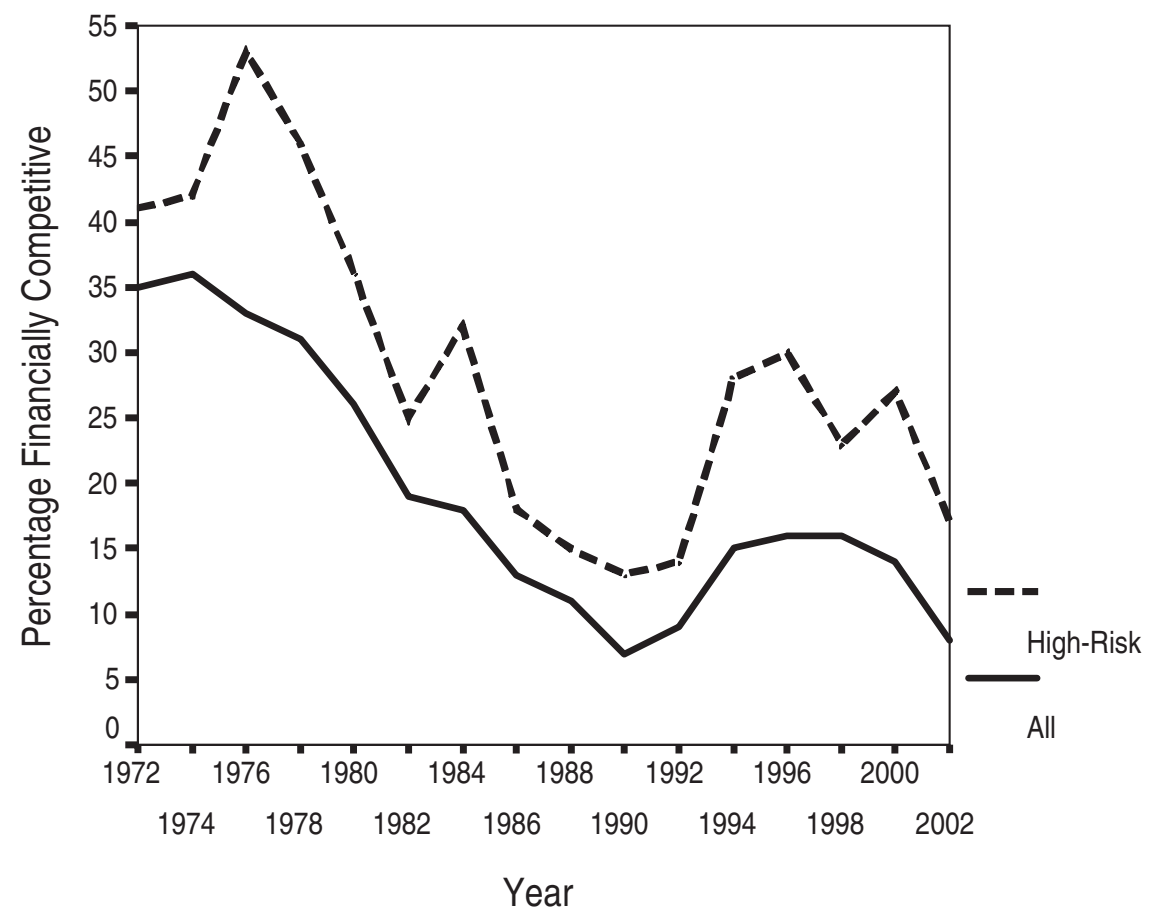

Note: Challengers classified as financially competitive if they accounted for at least 40 percent of combined challenger and incumbent spending. High-risk districts are those in which vote percentage of vote for presidential candidate of incumbent's party is less than national percentage.

Source: Data compiled by authors.

of incumbents in these contests were defeated. In contrast, only $7 \%$ of contests in which the challenger spent less than half a million dollars were highly competitive and not one incumbent in these contests was defeated. The reason so few incumbents in these high risk districts faced stiff competition is that only $17 \%$ of their challengers spent more than a million dollars while $68 \%$ spent less than half a million dollars.

Over time, the cost of running a competitive campaign for the House of Representatives has increased dramatically. Over the last three decades, the median spending of winners in House elections has grown at more than double the rate of inflation, going from $\$ 41,885$ in 1974 to $\$ 657,359$ in 2002 . While incumbents have been able to increase their fundraising to keep up with rising campaign costs, challengers have been much less successful. Figures 4 and 5 display the trend in the percentage of challengers who were financially competitive-accounting for at least $40 \%$ of total spending - in House elections between 1972 and 2002. In Figure 4 the trend is broken down by the competitiveness of the district. In Figure 5 the trend is broken down by the political experience of the challenger.
Challengers running in high-risk districts and challengers who have held elected office should be more capable of waging serious campaigns against incumbents than challengers in low- to moderate-risk districts or challengers who have not held elected office. However, the results displayed in Figures 4 and 5 show that even among these potentially formidable challengers there has been a fairly drastic decline in financial competitiveness since the 1970s. Taken together, these results demonstrate that even those challengers with the greatest potential for threatening incumbents are having more and more difficulty raising the funds necessary to wage competitive campaigns.

Further evidence of the declining financial competitiveness of challengers can be seen by examining the trend in median expenditures of incumbents and challengers in high-risk districts. These are districts whose partisan composition is most favorable to the challenger. However, between the 1992-1994 election cycle and the 2000-2002 election cycle, median spending by incumbents in high-risk districts rose from $\$ 596,000$ to $\$ 910,000$ while median spending by challengers in high-risk districts fell from $\$ 229,000$ to 


\section{Figure 5 Financial Competitiveness of House Challengers by Political Experience, 1972-2002}

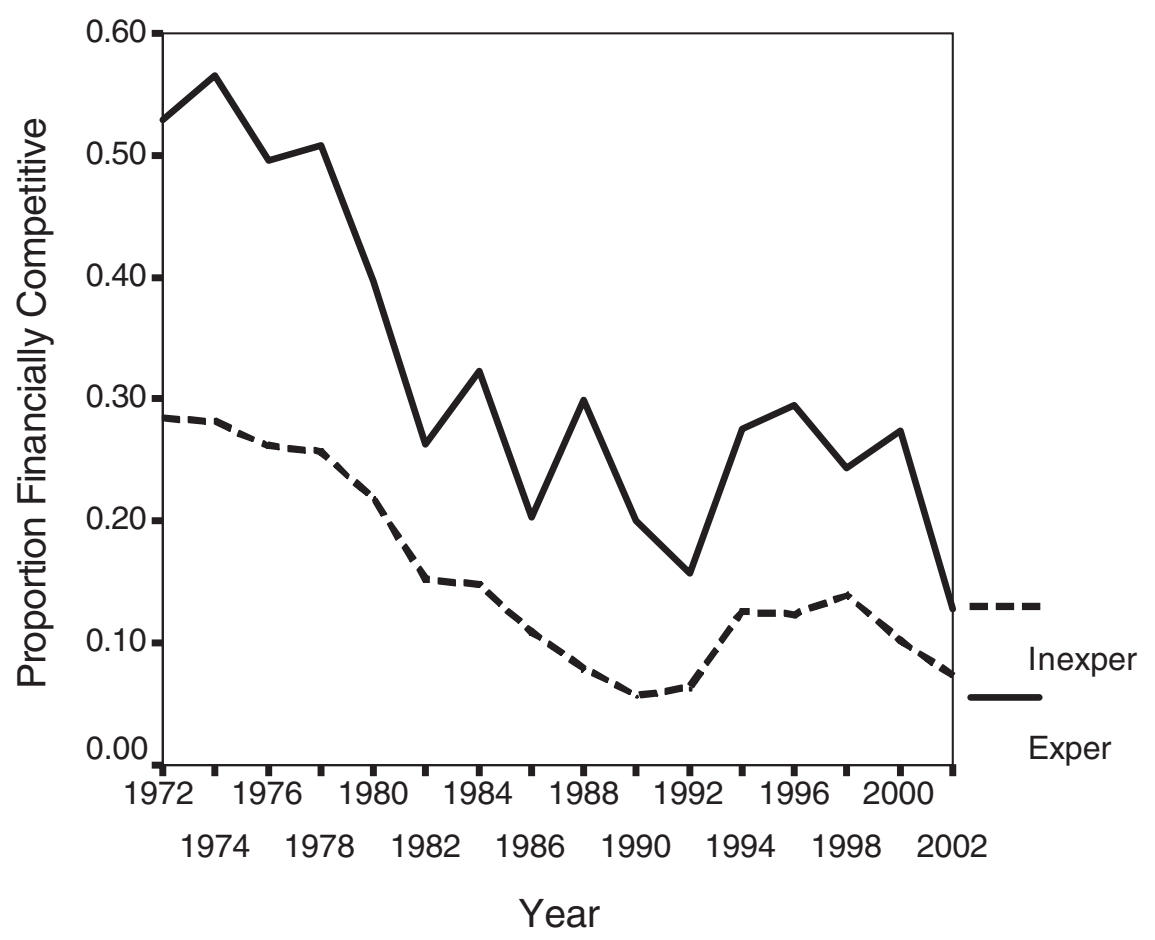

Note: Experienced challengers are those who have held any elected office.

Source: Data compiled by authors.

$\$ 198,000$ dollars. Even in potentially competitive districts, challengers have been falling farther behind incumbents in campaign spending. ${ }^{6}$

In order to estimate the effects of district partisanship, incumbency, and campaign spending on the competitiveness of House elections since the 1970s, we conducted regression analyses of the Democratic share of the major party vote in contested races in each election from 1972 through 2002. The results of these regression analyses are summarized in Table 4. We have grouped the results into four time periods with each time period consisting of four elections: 1972-78, 1980-86, 1988-94, and 1996-2002.

For each independent variable during each time period, we present the average unstandardized regression coefficient, the average score on the variable for all winning candidates, and the average impact of the variable on the vote share for winning candidates. The latter statistic is computed by multiplying the regression coefficient for each variable by the average advantage of winning candidates on that variable. In the case of incumbency and district partisanship, the raw score

${ }^{6}$ For additional documentation of this trend, see Figure 3 in the web appendix to this article on the Journal of Politics web site: http://www.journalofpolitics.org. is a measure of advantage. Incumbency is coded as +1 for incumbents, 0 for open seat candidates and -1 for challengers, so the average advantage score for winning candidates is the proportion of winning incumbents minus the proportion of winning challengers. District partisanship is measured by the normalized presidential vote so the average advantage score for winning candidates is the average normalized presidential vote for the winning candidate's party in each district. Campaign spending is measured by each candidate's percentage of combined Democratic and Republican campaign spending so the average advantage score for winning candidates is the average percentage of campaign spending by the winning candidate in each district minus 50 .

The results in Table 4 indicate that over the past 30 years, the direct effect of incumbency on the outcomes of House elections has actually been shrinking. After controlling for district partisanship and campaign spending, the estimated effect of incumbency on the vote in contested House elections fell from an average of 8.5 percentage points to an average of only 4.5 percentage points. Therefore, despite an increase in the mean score of winning candidates on the incumbency variable (meaning that a larger proportion of winners were incumbents and a smaller pro- 


\section{Table 4 Average Effects of Incumbency, District Partisanship, and Campaign Spending on Winning Candidates' Vote during Four Time Periods}

\begin{tabular}{llccrr}
\hline Variable & & $\mathbf{1 9 7 2 - 1 9 7 8}$ & $\mathbf{1 9 8 0 - 1 9 8 6}$ & $\mathbf{1 9 8 8 - 1 9 9 4}$ & $\mathbf{1 9 9 6 - 2 0 0 2}$ \\
\hline Incumbency & Coefficient & 8.50 & 6.35 & 4.64 & 4.45 \\
& Winners' Mean & .75 & .78 & .78 & .84 \\
& Net Impact & 6.38 & 4.95 & 3.62 & 3.74 \\
District & Coefficient & .34 & .38 & .41 & .46 \\
Partisanship & Winners' Mean & 4.22 & 5.70 & 5.83 & 8.36 \\
& Net Impact & 1.43 & 2.14 & 2.40 & 3.86 \\
Campaign\$ & Coefficient & .26 & .29 & .25 & .25 \\
Percentage & Winners' Mean & 69.08 & 76.68 & 79.41 & 81.88 \\
& Net Impact & 4.87 & 7.74 & 7.26 & 7.97 \\
\hline
\end{tabular}

Source: Data compiled by authors.

Note: Based on races with two major party candidates. Dependent variable is winning candidate's percentage of major party vote. Coefficients are unstandardized regression coefficients. District partisanship measured by normalized presidential vote. Net impact is based on coefficient $x$ mean value for winning candidates. Mean value used to compute net impact of campaign spending is winner's mean -50 .

portion were challengers), the estimated net impact of incumbency on winning candidates' margins fell from about 6.4 percentage points in the 1970s to just over 3.7 percentage points in the most recent period. These results are consistent with findings reported by Oppenheimer (2005) based on an examination of trends in the size of the sophomore surge and retirement slump during the same time period.

The declining contribution of incumbency to winners' margins has been more than offset, however, by the increasing contributions of district partisanship and campaign spending. Both the average regression coefficient for the district partisanship variable and the average advantage of winning candidates on this variable increased between the 1970s and the late 1990s. As a result, the net impact of district partisanship on winning candidates' margins increased from about 1.4 percentage point in the 1970 s to about 3.9 percentage points in the most recent period.

The average regression coefficient for the campaign spending variable changed very little between the 1970s and the late 1990s. However, the average advantage of winning candidates on this variable increased dramatically over this time period. During the 1970s, winning candidates accounted for an average of about $69 \%$ of total campaign spending. In the 1998-2002 elections, however, winning candidates accounted for an average of almost $82 \%$ of total campaign spending. As a result, the net impact of campaign spending on the winning candidates' margins increased from less than 5 percentage points in the 1970s to almost 8 percentage points in the most recent period.
The results in Table 4 indicate that since the 1970s campaign spending has replaced incumbency as the most important factor contributing to the margins of winning House candidates. However, the results in Table 4 reflect only the direct effects of these variables on the outcomes of House elections, not their indirect effects. Incumbency may affect the outcomes of elections not only directly but indirectly through its influence on campaign spending: an important and, according to the results presented earlier in this article, growing advantage of incumbency is the ability of incumbents to dominate their challengers financially. And district partisanship may affect the outcomes of elections not only directly but indirectly through its influence on both incumbency and campaign spending: the larger the majority that a party enjoys among voters in a district, the more likely it is that the district will be represented by an incumbent from the majority party and the larger the expected financial advantage of the majority party's candidate.

In order to examine the direct and indirect effects of district partisanship, incumbency, and campaign spending on the outcomes of House elections, we conducted path analyses of House election results during each of the time periods examined in Table 4 . The dependent variable in the path analyses is the Democratic share of the major party vote in all contested House races. Independent variables are district partisanship, measured by the normalized presidential vote, incumbency (coded as +1 for contests with Democratic incumbents, 0 for open seat races, and -1 for contests with Republican incumbents) and campaign spending, measured by the 
Table 5 Direct and Indirect Effects on Vote in Contested House Elections during Four Time Periods

\begin{tabular}{llccr}
\hline & & \multicolumn{3}{c}{ Effects } \\
\cline { 3 - 5 } Time Period & \multicolumn{1}{c}{ Variable } & Direct & Indirect & Total \\
\hline $1972-1978$ & District Partisanship & .202 & .336 & .538 \\
& Incumbency & .451 & .234 & .685 \\
$1980-1986$ & Campaign Spending & .421 & - & .421 \\
& District Partisanship & .238 & .433 & .671 \\
& Incumbency & .314 & .356 & .670 \\
$1988-1994$ & Campaign Spending & .520 & - & .520 \\
& District Partisanship & .283 & .409 & .692 \\
$1996-2002$ & Incumbency & .249 & .397 & .646 \\
& Campaign Spending & .508 & - & .508 \\
& District Partisanship & .337 & .490 & .827 \\
& Incumbency & .224 & .345 & .569 \\
\hline
\end{tabular}

Source: Data compiled by authors.

Note: Coefficients shown are path regression coefficients. Coefficients for election year dummy variables are not shown.

Democratic candidate's percentage of combined Democratic and Republican campaign spending in the race. The results of these path analyses are summarized in Table 5.

These results indicate that district partisanship and incumbency have strong indirect as well as direct effects on House elections. In addition, the results in Table 5 reveal several important trends in the effects of our three independent variables on election results. During the 1970s, incumbency had a much stronger direct effect on House election results than district partisanship, a slightly stronger direct effect than campaign spending, and by far the strongest total effect of the three independent variables. During the most recent period, however, incumbency had a much weaker direct effect on House election results than either district partisanship or campaign spending and district partisanship had by far the strongest total effect of the three independent variables. The decline in the direct effect of incumbency may itself reflect the growing importance of district partisanship since incumbents who represent safe districts have little incentive to cultivate their constituencies in order to expand their electoral coalitions beyond their party base.

The growing correlation among district partisanship, incumbency, and campaign spending means that the effects of these three variables tend to reinforce each other to a greater extent than in the past. Between the 1972-78 time period and the 1996-2002 time period the correlation between district partisanship and incumbency increased from .38 to .59 , the correlation between district partisanship and campaign spending increased from .45 to .69, and the correlation between incumbency and campaign spending increased from .66 to .86 . Not only do a much larger proportion of House districts now strongly favor one party, but the majority party is more likely to be represented by an incumbent and to enjoy an overwhelming advantage in campaign spending. The result is a pattern of reinforcing advantages that leads to extraordinarily uncompetitive elections.

\section{Discussion and Conclusions}

The evidence presented in this article indicates that declining competition in U.S. House elections is explained by two major factors: a shift in the partisan composition of House districts and a decline in the ability of challengers to compete financially with incumbents. Since the 1970s, and especially since 1992, there has been a substantial increase in partisan polarization among House districts. The number of marginal districts has been declining while the number of districts that are safe for one party has been increasing. Redistricting appears to have little or nothing to do with this trend: almost all of the change in district partisanship has occurred between redistricting cycles.

Along with the increasing polarization of House districts, there has been a substantial increase in par- 
tisan voting: voting in House elections is now much more consistent with voting in presidential elections. As a result of both of these trends, districts held by Democrats are now more strongly Democratic than in the past and districts held by Republicans are now more strongly Republican than in the past. There are far fewer Democrats and Republicans representing high-risk districts, districts whose partisan composition favors the opposing party, and far more Democrats and Republicans representing low-risk districts, districts whose partisan composition strongly favors their own party.

The effects of increasing partisan polarization have been reinforced by the second trend uncovered by our study - the decreasing financial competitiveness of House challengers. Even in the remaining high-risk districts most challengers lack the financial resources needed to wage competitive campaigns. Whether this trend reflects growing ability of incumbents to deter strong challengers, growing reluctance of contributors to offend powerful incumbents, or some other set of factors is not clear. The reasons for the declining financial competitiveness of House challengers certainly should be explored in future research.

The increasing proportion of safe districts and the declining financial competitiveness of challengers have important implications for congressional politics. The decreasing proportion of Democrats and Republicans representing marginal or high-risk districts means that there are fewer members who have an incentive to cross party lines on issues in order to appeal to supporters of the opposing party in their districts. The result is increased party-line voting and reduced bipartisan cooperation on major issues. Increasing polarization and declining competition also mean that both parties have fewer seats at risk in elections. The result is diminished seat turnover and smaller seat swings. This helps to explain why, despite the relatively small size of their majority, Republicans have been able to maintain control of the House since their 1994 takeover.

\section{Acknowledgments}

We would like to thank the three anonymous reviewers for the Journal of Politics and Linda Fowler for their helpful comments and suggestions. Elizabeth Fricker provided valuable editorial assistance in the preparation of the manuscript. An earlier version of this article was presented at the 2005 Annual Meeting of the Southern Political Science Association, Intercontinental Hotel, New Orleans, Louisiana.

Manuscript submitted 30 March 2004

Manuscript accepted for publication 10 June 2005

\section{References}

Abramowitz, Alan I. 1991. "Incumbency, Campaign Spending, and the Decline of Competition in U.S. House Elections." Journal of Politics 53 (1): 34-56.

Abramowitz, Alan I., and Kyle Saunders. 1998. "Ideological Realignment in the U.S. Electorate." Journal of Politics 60 (3): 634-52.

Bartels, Larry M. 2000. "Partisanship and Voting Behavior, 1952-1996." American Journal of Political Science 44 (1): 35-50.

Bishop, Bill. 2004. "The Schism in U.S. Politics Begins at Home." Austin American-Statesman, April 4, p. A1.

Black, Earl, and Merle Black. 2004. The Rise of Southern Republicans. Cambridge: Harvard University Press.

Broder, David. 2004. "No Vote Necessary." Washington Post, November 11, p. A37.

Brooks, David. 2001. "One Nation, Slightly Divisible." Atlantic Monthly, December: 53-65.

Campbell, James E. 2002. "Is the House Incumbency Advantage Mostly a Campaign Finance Advantage?" Paper presented at the Annual Meeting of the New England Political Science Association, Portland, Maine.

Campbell, James E. 2003. "Campaign Financing and the Stagnation of Congressional Elections." In Life After Reform: Foreseeing the Bipartisan Campaign Reform Act in Practice, eds. Michael Malbin and Robin Kolodny. Lanham, MD: Rowman and Littlefield, pp. 141-58.

Cox, Gary W., and Jonathan N. Katz. 1996. "Why Did the Incumbency Advantage in U.S. House Elections Grow?" American Journal of Political Science 40 (2): 478-97.

Dionne, E. J. 2003. “One Nation Deeply Divided." Washington Post, November 7, p. A31.

Fiorina, Morris P., Samuel J. Abrams, and Jeremy C. Pope. 2004. Culture War? The Myth of a Polarized America. New York: Pearson Longman.

Gelman, Andrew, and Gary King. 1994. "Enhancing Democracy through Legislative Redistricting." American Political Science Review 88 (3): 541-59.

Gimpel, James G., and Jason E. Schuknecht. 2003. Patchwork Nation: Sectionalism and Political Change in American Politics. Ann Arbor: University of Michigan Press.

Glazer, Amihai, Bernard Grofman, and Marc Robbins. 1987. "Partisan and Incumbency Effects of 1970 Redistricting." American Journal of Political Science 31 (3): 680-707.

Gopoian, J. David, and Darrell M. West. 1984. “Trading Security for Seats: Strategic Considerations in the Redistricting Process." Journal of Politics 46 (4): 1080-96.

Hill, Steven. 2005. "Schwarzenegger vs. Gerrymander." New York Times, February 19, p. A15.

Hunter, James Davison. 1995. Before the Shooting Begins: Searching for Democracy in America's Culture Wars. New York: Free Press. 
Jacobson, Gary C. 2000. "Party Polarization in National Politics: The Electoral Connection." In Polarized Politics: Congress and the President in a Partisan Era, eds. Jon R. Bond and Richard Fleisher. Washington: Congressional Quarterly Press, pp. 9-30.

Kazee, Thomas A. 1983. "The Deterrent Effect of Incumbency on Recruiting Challengers in U.S. House Elections.” Legislative Studies Quarterly 8 (3): 469-80.

Levendusky, Matthew S. 2004. "Sorting, Not Polarization: The Changing Nature of Party ID and Ideology in the U.S. Electorate." Presented at the Annual Meeting of the American Political Science Association.

Levitt, Steven D., and Catherine D. Wolfram. 1997. "Decomposing the Sources of Incumbency Advantage in the U.S. House." Legislative Studies Quarterly 22 (1): 45-60.

Lyons, Michael, and Peter F. Galderisi. 1995. "Incumbency, Reapportionment and U.S. House Redistricting." Political Research Quarterly 48 (4): 857-71.

Mannan, Rossana. 2004. "UCI Professors Examine Political Divide Among States." New University, November 8: News.

Mayhew, David R. 1974. Congress: The Electoral Connection. New Haven: Yale University Press.

Monmonier, Mark. 2001. Bushmanders and Bullwinkles: How Politicians Manipulate Electronic Maps and Census Data to Win Elections. Chicago: University of Chicago Press.
New York Times. 2004. "Elections with No Meaning." New York Times, February 14, p. A14.

Oppenheimer, Bruce I. 2005. "Deep Red and Blue Congressional Districts." In Congress Reconsidered, 8th ed., eds. Lawrence C. Dodd and Bruce I. Oppenheimer. Washington: Congressional Quarterly Press, pp. 135-57.

Paulson, Amanda. 2004. "Suburb Shift Turns State Blue." Christian Science Monitor, July 16, p A1.

Stonecash, Jeffrey M., Mark D. Brewer, and Mack D. Mariani. 2003. Diverging Parties: Social Change, Realignment, and Party Polarization. Boulder: Westview Press.

Tufte, Edward R. 1973. "The Relationship Between Seats and Votes in Two-Party Systems." American Political Science Review 67 (2): 540-55.

Alan I. Abramowitz is professor of political science, Emory University, Atlanta, GA 30322. Brad Alexander is a Ph.D. Student in political science, Emory University, Atlanta, GA 30322. Matthew Gunning is a Ph.D. Student in political science, Emory University, Atlanta, GA 30322. 